\title{
Stosunki polityczne między USA a Federacją Rosyjską w latach 1991-2001
}

$\coprod_{\text {dzy sobą, czy to poprzez rozwój wymiany handlowej, czy też informa- }}^{\text {udzie od zarania dziejów zmierzali do nawianzywania kontaktó miè }}$ cji o innych krajach, dzięki którym rozwijały się stosunki kulturalne. Kontakty te pogłębiały silnie rozwijające się stosunki społeczne, które z czasem doprowadzały również do konfliktów między rodami, plemionami, miastami czy państwami.

Z przekazów starożytnych historyków, którzy powoli stawali się prekursorami naukowego poznania relacji międzynarodowych wiemy, iż stosunki między narodami zaczęły być istotnym czynnikiem życia w ,wewnętrznie zorganizowanych grupach społecznych, stając się zarazem coraz bardziej interesującym przedmiotem wielorakich rozważań" ". Problemy te były ważne m.in. dla Tukidydesa, Platona i Arystotelesa, którzy rozumieli potrzebę ugruntowania wiedzy na temat przyczyn wchodzenia jednych grup społecznych w stosunki z innymi grupami, narodami. Platon, podkreślając rolę mężów stanu, nazywając ich „stróżami państwa”, tworzył kanony zachowań, według rozumu, filozofii i polityki, łącząc je z rozwagą, a ,politykę nazywał umiejętnością państwową i z tej racji panującą nad innymi"2. Jednocześnie akcentował umiejętność współpracy i współistnienia narodów, koegzystujących w równowadze sił, stosunkach opartych na wzajemnym poszanowaniu i równości. Wszyscy oni dążyli do podkreślenia głównej zasady, że „państwa powinny zmierzać przede wszystkim do osiagnnięcia szczęścia obywateli, które jest ich ostatecznym celem"3.

Prenowożytne stosunki międzynarodowe charakteryzowały się sporadycznością, w porównaniu do kolejnych epok kontaktów nawiązywanych

1 J. Kukułka, Teoria stosunków międzynarodowych, Warszawa 2000, s. 47.

2 Ibidem, s. 14.

3 Platon, Rzeczpospolita, Kraków 1928, s. 305. 
przez poszczególne narody świata. Dopiero średniowiecze zwiększyło intensywność interakcji i podniosło stopień ożywienia światowych stosunków wzajemnych, dzięki bezpośredniej drodze morskiej do Indii czy odkryciu Ameryki.

Na bazie ekspansji europejskiej i dynamiki rozwoju kontaktów Europa kontra reszta świata, nastąił rozwój myśli politycznej analizującej wydarzenia. Szczególną rolę w tej materii jako analityk stosunków zewnętrznych odegrał Niccolo Machiavelli, włoski pisarz polityczny i polityk ${ }^{4}$, który uważał, że każde państwo ma prawo dążyć do panowania nad innymi, bo jest to wynik naturalnego prawa każdego narodu do chęci rywalizacji z innymi, w celu maksymalizacji własnego dobra. Wierzył on w dynamikę stosunków między narodami, wyznając zasadę, że rozumniejszy, zdolniejszy i silniejszy ma prawo domagać się od słabszego narodu uległości i służebności. Religię traktował przy tym jako środek do celu i instrument rządzenia, towarzyszący dynamicznej ekspansji państwa, polemizując na tym polu z Erazmem z Rotterdamu ${ }^{5}$.

Ostateczne załamanie się średniowiecznego systemu jedności świata chrześcijańskiego pod przywództwem papieża i cesarza, przy jednoczesnym stworzeniu europejskiego systemu państw, będącego zalążkiem obecnego światowego systemu międzynarodowego, nastapiło po długotrwałych i krwawych wojnach religijnych w połowie XVII wieku, w wyniku zawarcia pokoju westfalskiego (1648), kończącego wojnę trzydziestoletnią. Datę tę uznaje się za cezurę nowożytnych stosunków międzynarodowych, w których to występuje stała tendencja do tworzenia systemu równowagi sił (pojmowanego jako pewien porządek międzynarodowy), pluralizmu suwerennych państw, mechanizmu budowania koalicji czy też globalnych wojen, w wyniku których państwa zwycięskie pełniły w systemie międzynarodowym funkcję przywódców, ustanawiając reguły, zasady i instytucje międzynarodowe w globalnym systemie politycznym i ekonomicznym.

4 Postać kontrowersyjna, do dziś stanowiąca obiekt sporów i analiz. Przez jednych nazwany jedynym odkrywcą prawdziwego oblicza „męża stanu”, przez drugich „amoralnym i cynicznym kameleonem politycznym”. Za: J. Kukułka, Teoria stosunków ..., op. cit., s. 25.

5 Gdy Machiavelli mówił o rywalizacji państw, Erazm pisał o ich koegzystencji w zgodzie i miłości, o osłabianiu antagonizmów pomiędzy narodami. Potępiał dążenia ambitnych władców, aby rządzić i podbijać inne narody, wychwalał władców dążących do pokoju, podkreślał równość między narodami i ich prawo do suwerenności. 
Jednocześnie podstawową wartością w europejskiej dyplomacji staje się racja stanu, usprawiedliwiająca każde działanie, które utrwalałoby i powiększało potęgę świata ${ }^{6}$. Tak więc racja stanu i idee merkantylistyczne zdominowały siedemnastowieczną Europę, w której zdolność do prowadzenia wojny zależała od zysków czerpanych ze świata kolonialnego, a sama wojna była drogą do osiagnięcia przez naród siły i bogactwa poprzez rujnowanie rywali ${ }^{7}$. Od tej pory ,silniejsi będą dążyć do dominacji, słabsi będą się temu przeciwstawiać, tworząc koalicje w celu zwiększenia ich indywidualnej siły" ${ }^{\text {. }}$

Tworzył się nowoczesny system międzynarodowy, nowy rodzaj relacji między ówczesnymi potęgami. Cechowało go wspólne działanie środkami pokojowymi i takie sterowanie systemem powiązań, aby przywracać równowagę sił w systemie światowym, formułował projekt dokumentu, który był syntezą zasad stosunków międzynarodowych o nazwie „projekt deklaracji prawa narodów" ". Jego gwarantem stał się dyrektoriat pięciu państw: Wielkiej Brytanii, Austrii, Rosji, Prus i Francji. „Tworzyły one podwaliny najdłuższego w historii stosunków europejskich porządku międzynarodowego, w którym narody mogły rywalizować ze sobą na pewnym poziomie, ale miały też zgodnie decydować o sprawach związanych ze stabilizacją na kontynencie" $"$.

Postępujący proces internacjonalizacji i współzależności sprzyjał również współdziałaniu państw na rzecz indywidualnych i zbiorowych interesów, które pozbawione były często moralnych aspektów, a wyposażone $\mathrm{w}$,,agresywny i ekspansywny internacjonalizm, wyrastający z przekonania, iż interesy partykularne mogą być realizowane bez względu na interesy

6 T. Łoś-Nowak, Stosunki międzynarodowe. Teorie-systemy-uczestnicy, Wrocław 2000, s. 13.

7 A. Gałganek, Geneza stosunków międzynarodowych i ich teoria, w: Stosunki międzynarodowe, pod red. W. Malendowskiego i Cz. Mojsiewicza, Wrocław 1998, s. 13.

8 Przykładem może tu być rola Wielkiej Brytanii jako ,języczka u wagi” w rozgrywce Francja kontra reszta świata. Wielka Brytania od ponad 150 lat skutecznie układała się niemal z każdym, aby zrównoważyć wyrosłą za Richelieu'go potęgę francuską. Sojusze te były tak silne i zdeterminowane postawą Anglii, że stopniowo wyczerpały bogactwo Francji. Za: H. Kissinger, Dyplomacja, Warszawa 1996, s. 70.

9 Projekt ten poruszał kwestie suwerenności i równości państw, nieinterwencji czy swobody wyboru formy rządów. Interes narodu został podporządkowany ogółowi. Wolność i równość to gwarant rządów zgodnych z prawem narodów. Wojna jest usprawiedliwiona tylko wtedy, gdy jest wynikiem obrony swej suwerenności, wolności czy własności. Za: J. Kukułka, Teoria stosunków ..., op. cit, s. 48.

10 T. Łoś-Nowak, Stosunki międzynarodowe ..., op. cit., s. 18. 
narodowe i państwowe innych państw, wbrew nim, a nawet ich kosztem. Tę tendencję nazwano imperializmem" "11.

Stosunki międzynarodowe nie powstają ani nie są realizowane w próżni. Ich źródła, kształt, intensywność czy przebieg zależą od wielu czynników. Należą do nich czynniki wewnętrzne, charakterystyczne dla poszczególnych podmiotów międzynarodowych oraz czynniki zewnętrzne, czyli wpływ środowiska międzynarodowego. Wielu badaczy współczesnych stosunków międzynarodowych wskazuje na dominujący w ostatnich latach rozwój trzech dziedzin przekształcających ich istotę. Są to: rewolucja technologiczna, wysoki poziom współzależności ekonomicznej oraz szeroko pojęty globalizm.

W nauce o stosunkach międzynarodowych pojęcie ,uczestnik” jest stosowane zamiennie z pojęciami ,podmiot” stosunków międzynarodowych i ,aktor”. R. Vukadinovic uczestnikiem nazywa „każdego nosiciela jakiejś aktywności, która wpływa na stosunki międzynarodowe w sensie pozytywnym lub negatywnym"12. Aktywność ta powinna być świadomym i zamierzonym działaniem, którego skutki wykraczają poza granice kraju. Niewątpliwie takimi ,aktorami” są przywódcy wielkich państw w dobie multimedialnej komunikacji globalnej oraz grupy zorganizowane zależne od nich. „Kolejnym rodzajem podmiotowych uczestników stosunków międzynarodowych są organizacje międzynarodowe, choć ich istnienie w systemie międzynarodowym jest stosunkowo krótkie, to jednak dynamika, z jaką oddziałują na stosunki ogólnoświatowe, rola, jaką się im przypisuje czy cele, jakie się im stawia, są niewątpliwie ogromne"13.

W stosunkach międzynarodowych pojęcie ,zimna wojna” po raz pierwszy zostało użyte w przemówieniu wygłoszonym w 1947 r. przez doradcę prezydenta Harry'ego Trumana, przewodniczącego Komisji Energii Atomowej - Bernarda Barucha przed stanową izbą ustawodawczą w Columbii ${ }^{14}$.

11 R. Kuźniar, Stosunki międzynarodowe - istota, uwarunkowania, badanie, w: Stosunki międzynarodowe. Geneza, struktura, dynamika, pod red. E. Haliżak i R. Kuźniara, Warszawa 2000, s. 18.

12 Z. Czachór, Uczestnicy stosunków międzynarodowych, w: Stosunki międzynarodowe, pod red. W. Malendowskiego i Cz. Mojsiewicza, Wrocław 1998, s. 43.

13 Jak podaje T. Łoś-Nowak, Stosunki międzynarodowe ..., op. cit., istnieją dwa stanowiska co do roli organizacji międzynarodowych: nurt neorealistyczny akcentuje marginalny wpływ i bezsilność w świecie rządzonym przez państwa i bliski neorealizmowi, podkreślający znaczenie, możliwości i pozycję w systemie.

14 Tekst przemówienia spopularyzowany przez amerykańskie media przygotował Herbert Swop. 
Definicji samej „zimnej wojny” jest wiele. Najczęściej definiuje się ją jako „stan otwartej wrogości i dwubiegunowej rywalizacji nacechowanej w wysokim stopniu napięciem i konfrontacją między dwoma mocarstwami oraz dwoma systemami społeczno-politycznymi i gospodarczymi, nie przekraczającej jednak progu konfliktu zbrojnego"15.

W polskiej literaturze politologicznej ciekawej interpretacji pojęcia „zimnej wojny” dokonał Janusz Stefanowicz, określając ją jako taki stan stosunków pomiędzy mocarstwami i państwami o przeciwstawnych ideologiach, „w którym nad elementami porozumienia przeważają czynniki konfliktu i zła wola. Celem polityki zagranicznej staje się wówczas nie współpraca ani nawet nie unikanie sporów, lecz ich prowokowanie z zamiarem osłabienia partnera, bez przewidywania użycia siły zbrojnej, lecz za dopuszczeniem takiej możliwości" ${ }^{\prime 16}$.

Najczęściej w literaturze za symboliczny początek zimnowojennej rywalizacji uważa się przemówienie Winstona Churchilla wygłoszone w Fulton 5 III 1946 r., w którym, krytykując nazbyt ekspansjonistyczną politykę Związku Radzieckiego, proponował ścisły sojusz w celu przeciwstawienia się agresywnej polityce ZSRR stwierdzając, że od Szczecina do Triestu zapadła „żelazna kurtyna”, poza którą znajduje się już tylko „strefa sowiecka”.

Na przyczyny ,zimnej wojny” składa się szereg zdarzeń i procesów wzajemnie ze sobą powiązanych, mających swój początek już w konsekwencjach II wojny światowej, w splocie i początkach ideologicznej rywalizacji, a także szeregu czynników militarnych. Do najważniejszych wydarzeń inicjujących ,zimną wojnę” należą:

- ustalenia konferencji w Teheranie i Jałcie,

- zrzucenie bomby atomowej na Hiroszimę i Nagasaki w sierpniu 1945 r.,

- przebieg poczdamskiej konferencji Wielkiej Trójki utrzymany w atmosferze ,atomowej argumentacji”,

- kryzys irański w 1946 r.,

- zapowiedź amerykańskiej pomocy dla przemysłu Niemiec, przedstawiona $\mathrm{w}$ przemówieniu wygłoszonym przez sekretarza stanu USA Jamesa Byrnesa, we wrześniu 1946 r. w Stuttgarcie,

- doktryna Trumana i Plan Marshalla z 1947 r. ${ }^{17}$

15 W. Malendowski, Zimna wojna, Poznań 1994, s. 18. Za: G. F. Kennan, The United States and the Soviet Union 1917-1976, „Foreign Affairs” 1976, nr 4, s. 672.

16 W. Malendowski, op. cit., s. 19.

17 W. Malendowski, op. cit., s. 20. 
Narastanie zimnowojennej konfrontacji nastąpiło w drugiej fazie w latach 1948-1953 w wyniku pierwszego kryzysu berlińskiego i blokady Berlina, a w konsekwencji podziału Niemiec na Wschodnie i Zachodnie i ustanowieniu kontroli ZSRR nad Europą Środkowo-Wschodnią. Okres ten obfituje w wiele znaczących wydarzeń, które pogłębiły przepaść między tworzącymi się dwoma blokami; do najważniejszych z nich należą: przejęcie władzy przez komunistów w Czechosłowacji w 1948 r., wojna domowa, rewolucja, a w konsekwencji proklamowanie Chińskiej Republiki Ludowej w 1949 r. (w tym samym roku utworzono sojusz obronny państw zachodnich - NATO), a także wybuch wojny koreańskiej w 1950 roku.

Okres ten uznawany jest w historii stosunków międzynarodowych za apogeum zimnowojennego współzawodnictwa ${ }^{18}$. Według prof. Zbigniewa Brzezińskiego, w czasie trwania tych pierwszych faz Ameryka zachowywała postawę defensywną, przejawiająca się m.in. w potępieniu ZSRR za podporządkowanie sobie Europy Środkowo-Wschodniej, jednak go nie zakwestionowała; reakcja na zachowania przeciwnika zawsze była ostrożna i nawet doktryna ,zmasowanego ataku” miała raczej charakter defensywny niż ofensywny.

Śmierć Stalina w 1953 r. zakończyła drugą fazę ,zimnej wojny” i wydawało się, że obie strony chcą polepszyć wzajemne stosunki, ,ale Zachód sprawiał wrażenie gotowego do ofensywy"19. W konsekwencji amerykański sekretarz stanu John Dulles publiczne zaangażował Amerykę w „wyzwolenie” Europy Środkowej i Wschodniej od radzieckiej dominacji. Trzecia faza datuje się na lata 1954-1962 i jest okresem, w którym przeplatają się elementy odprężenia w stosunkach między dwoma blokami i elementy ostrych kryzysów. Na elementy pewnego rodzaju odprężenia złożyły się decyzje ZSRR dotyczące zrzeczenia się roszczeń terytorialnych w stosunku do Turcji i przekazania Finlandii bazy w Porkkala-Udd, ogłoszono neutralność Austrii, zakończono stan wojny między ZSRR a Niemcami - co w konsekwencji doprowadziło do nawiązania stosunków dyplomatycznych z Republiką Federalną Niemiec w roku 1955. Sukcesem zakończyła się również międzynarodowa konferencja w Genewie w roku 1954 w sprawie uregulowania problemów koreańskiego i indochińskiego. Wyrazem nawiązania dialogu między USA a ZSRR była

18 J. Kukułka, Historia współczesnych stosunków międzynarodowych, Warszawa 1996, s. 86.

19 Z. Brzeziński, Spadek po zimnej wojnie, Warszawa 1993, s. 177-178. 
wizyta radzieckiego przywódcy Nikity Chruszczowa w Stanach Zjednoczonych we wrześniu 1959 r., jak pisze Henry Kissinger, „główny nacisk położono nie na treść, lecz na atmosferę"20. Wiele kontrowersyjnych spraw udało się rozwiązać w duchu międzynarodowej współpracy - różnice jednak nadal dotyczyły kwestii Berlina ${ }^{21}$. I to właśnie kwesta Niemiec doprowadził do pojawienia się pewnych oznak narastającego kryzysu, spowodowanego reakcją na przyjęcie RFN najpierw do państw Unii Zachodnio-Europejskiej, a później do NATO, co w konsekwencji doprowadziło do natężenia kryzysu berlińskiego, czego wyrazem była budowa muru w Berlinie w 1961 roku.

W 1962 r. doszło do wybuchu najpoważniejszego w dziejach powojennych kryzysu, zwanego kubańskim kryzysem rakietowym, który doprowadził świat niemal do krawędzi wojny jądrowej ${ }^{22}$. Lata 1963-1969 określone zostały przez prof. Włodzimierza Malendowskiego jako faza kształtowania się przesłanek odprężenia, zapoczątkowana rokowaniami i przyjęciem memorandum dotyczącego porozumienia między Związkiem Radzieckim a Stanami Zjednoczonymi w sprawie utworzenia ,gorącej linii" telefonicznej oraz podpisaniem w Moskwie układu o zakazie prób z bronią nuklearną w atmosferze, przestrzeni kosmicznej i pod wodą. Pośrednia rywalizacja między mocarstwami skupiła się na pozaeuropejskich regionach świata, np. na wojnie wietnamskiej (1965-1973), gdzie USA bezpośrednio w niej uczestniczyły, dokonując interwencji, natomiast ZSRR ograniczał się do wspierania Wietnamu bronią i środkami materialnymi oraz doradcami, stając się, wg Kissingera, „współuczestnikiem” w tej wojnie ${ }^{23}$.

Do pewnego rodzaju „normalizacji” stosunków pomiędzy RFN a ZSRR (1970 r.), Polską (1970 r.), NRD (1972 r.) oraz Czechosłowacją (1973 r.) doszło w piątej fazie, określanej jako „detente” - czyli odprężenie. Faza ta charakteryzowała się podpisaniem długo oczekiwanego układu w sprawie Berlina Zachodniego, zbliżeniem amerykańsko-radzieckim, czego wyrazem było zawarcie w 1972 r. traktatu o ograniczeniu systemów obrony przeciwrakietowej, układu w sprawie ograniczenia zbrojeń strategicznych SALT I i SALT II w 1979 r. Podjęto również rokowania zwane wiedeńskimi rokowaniami rozbrojeniowymi, dotyczące redukcji zbrojeń

\footnotetext{
20 H. Kissinger, op. cit., s. 637.

21 H. Kissinger, op. cit., s. 638.

22 W. Malendowski, op. cit., s. 67-71.

23 H. Kissinger, op. cit., s. 681-772.
} 
i sił zbrojnych w Europie Środkowej. Wydarzeniem potwierdzającym odprężenie w stosunkach amerykańsko-radzieckich była wizyta w Moskwie w 1972 r. prezydenta Richarda Nixona. Interwencja radziecka w Afganistanie położyła kres „,erze detente” w grudniu 1979 r., rozpoczynając tym samym szóstą fazę z lat 1980-1985, zwanej ,nową zimną wojną"24.

Zdanie Henry'ego Kissingera, że ,zimna wojna rozpoczęła się, gdy Ameryka oczekiwała ery pokoju; dobiegła końca, gdy Ameryka sposobiła się na okres dłuższego konfliktu"25, najbardziej oddaje klimat okresu, w którym to przesłanki znacznej poprawy relacji amerykańsko-radzieckich zaczęły się kształtować. Administracja prezydenta Reagana zaczęła bowiem dostrzegać rosnące napięcia systemu politycznego, gospodarki sowieckiej, a także możliwość wygranej ze Związkiem Radzieckim na płaszczyźnie zbrojeniowej. Postanowiła więc rozpocząć agresywną politykę, łącząc konfrontacyjny styl z ryzykowną dyplomacją. Agresja ta przejawiała się na gruncie polityki międzynarodowej i polegała m.in. na udzielaniu pomocy finansowej i wojskowej dla ruchu oporu w Afganistanie, poparciem dla „Solidarności” w Polsce, ograniczaniu sowieckich wpływów dewizowych w świece poprzez sztuczne obniżenie cen ropy naftowej oraz opóźnienie budowy gazociągu syberyjskiego do Europy Zachodniej.

Punktem zwrotnym znacznej poprawy stosunków amerykańsko-radzieckich była niewątpliwie zmiana na stanowisku sekretarza generalnego KC KPZR w marcu 1985 r., a w konsekwencji wybór Michaiła Gorbaczowa i ogłoszenie przez niego programu pierestrojki (przebudowy) oraz głasnosti (jawności), wyrażone w książce Przebudowa i nowe myślenie ${ }^{26}$. $\mathrm{W}$ polityce wewnętrznej program ten zapowiadał utworzenie silnego systemu prezydenckiego wraz ze stopniowym włączeniem społeczeństwa w system sprawowania władzy poprzez demokratyczną ordynację wyborczą. W polityce zagranicznej natomiast innowacja Gorbaczowa polegała na wprowadzeniu w życie koncepcji pokojowego współistnienia różnych systemów politycznych oraz na jawności poczynań władzy oraz odtajnienia historii ZSRR. Gorbaczow, uznając, iż „we współczesnym

24 Leksykon współczesnych ..., pod red. Cz. Mojsiewicza, s. 364.

25 H. Kissinger, op. cit, s. 839.

26 R. Koslowski, F. V. Kratochwil, Understanding Change in International Politics: The Soviet Empire's Demise and the International System, informacje ze zbiorów Columbia International Affairs Online CIAO, zamieszczone na stronach www.ciaonet.org (stan na 1 marca 2002). 
świecie wszyscy w coraz większym stopniu uzależniamy się od siebie nawzajem, stajemy się sobie nawzajem potrzebni" ${ }^{27}$, doszedł do wniosku, że „,nadszedł czas, by zerwać z patrzeniem na politykę zagraniczną z pozycji imperialnych, gdyż niezbędna jest równowaga" ${ }^{28}$.

Wychodząc od planu ograniczenia i kontrolowania „wyścigu zbrojeń”, który przeszedł do historii pod nazwą ,planu Gorbaczowa”, zaproponował ,wkroczenie w trzecie tysiąclecie bez broni jądrowej, na podstawie wzajemnie możliwych do przyjęcia i ściśle kontrolowanych porozumień" ${ }^{29}$. Plan ten spotkał się z pozytywnym odzewem ze strony społeczności międzynarodowej.

Na XXVII zjeździe KPZR w 1986 r. Gorbaczow apelował już nie tylko o podejmowanie działań zmierzających do budowy wzajemnego zaufania dwóch mocarstw, ale również oświadczył, iż „stworzony przez ZSRR strategiczny i niezawodny parytet wojskowy ogranicza agresywne plany imperializmu na tyle, aby uniemożliwić rozpętanie przez niego wojny nuklearnej, w związku z czym doktryna radziecka ma niewątpliwie charakter obronny, podkreślając jednocześnie, że przy rozwiązywaniu sporów niedopuszczalna jest przemoc" ${ }^{\text {"30. }}$.

Reakcje Zachodu na tak nagłą i radykalną zmianę postawy Związku Radzieckiego były różne - od euforii po skrajny sceptycyzm, niewątpliwie jednak spowodowały szeroką dyskusję na temat przyszłych kierunków oraz ewentualnej zmiany polityki zagranicznej Stanów Zjednoczonych ${ }^{31}$.

27 J. Kukułka, Historia współczesna ..., op. cit., s. 417.

${ }^{28}$ Ibidem.

29 J. Kukułka, Historia wspótczesna ..., op. cit., s. 417. Plan ten przewidywał trójstopniowe osiaganie celu. Pierwszy etap miał obejmować od 5 do 8 lat, w których to USA i ZSRR zredukowałyby do połowy bronie jądrowo-wodorowe będące w stanie dosięgnąc terytorium drugiego państwa (w konsekwencji po każdej ze stron pozostałoby po niecałe 6 tys. ładunków). Drugi etap, rozpoczęty nie później niż w 1990 r., miał trwać od 5 do 7 lat i polegałby na dołączeniu do dwóch mocarstw pozostałych państw posiadających broń jądrową przy jednoczesnej likwidacji przez wszystkie państwa taktycznej broni jądrowej i zaprzestaniu prób z bronią jądrową. Trzeci etap ograniczyłby się do przeprowadzenia redukcji pozostałych rodzajów broni jądrowej oraz zawarcia powszechnego porozumienia państw zakazującego odradzania się tego rodzaju broni.

30 J. Kukułka, Historia wspótczesna ..., op. cit., s. 419, 46.

31 Do grona sceptyków nie wierzących w szczerość i intencje Gorbaczowa oraz podważających tezy przedstawione przez niego w Przebudowie i nowym politycznym myśleniu należał m.in. G. Kennan. Uważał on mianowicie, iż Gorbaczow jest ,idealistą wierzącym szczerze w sen, który nazywa socjalizmem". Natomiast Henry Kis- 
Powołana przez administrację Ronalda Reagana Grupa Specjalna, mającą na celu dokonanie analizy nowej polityki zagranicznej ZSRR, przedstawiła raport, na podstawie którego uznała konieczność weryfikacji polityki zagranicznej Stanów Zjednoczonych wobec ZSRR i zdecydowaną reakcję na inicjatywy radzieckie stwarzające szansę na budowę trwałych środków ewentualnej współpracy nie tylko w sferze rozbrojeniowej. Konsekwencją takiej postawy była rosnąca wiara w szczerość intencji Gorbaczowa, przejawiająca się w pogłębianiu wzajemnej współpracy, zapoczątkowanej podpisaniem trzynastu porozumień amerykańsko-radzieckich w Waszyngtonie w 1986 r. w sprawie współpracy m.in. w dziedzinie kultury, ochrony zdrowia, oświaty i sportu ${ }^{32}$ oraz kontynuacją intensywnych rokowań w kwestiach rozbrojeniowych, zapoczątkowanych w Genewie na początku tegoż roku.

Przykładem współpracy obu mocarstw są także negocjacje genewskie w sprawie ograniczenia zbrojeń jądrowych, których finał został osiagnięty w postaci podpisania układu o likwidacji rakiet jądrowych średniego i krótszego zasięgu w Waszyngtonie w grudniu 1987 roku.

Od czasu zakończenia II wojny światowej do 1987 r. odbyło się zaledwie czternaście międzynarodowych spotkań na „szczycie”, w których udział brali przywódcy USA i ZSRR. Konferencja w Waszyngtonie w grudniu 1987 r. miała być piętnastym ,szczytem” dwóch mocarstw. Przywódcy mieli rozmawiać nie tylko o spornych kwestiach, takich jak przyszłość traktatu ABM z 1972 r., postępy w negocjacjach nad układem START czy kwestii budowy systemu SDI, ale również o przestrzeganiu praw człowieka, sprawach poszczególnych regionów, stosunkach bilateralnych i wreszcie o układzie INF. Nikt jednak nie łączył z nią wielkich nadziei ani bynajmniej nie dostrzegał jej przełomowego znaczenia ${ }^{33}$. $\mathrm{Z}$ perspektywy czasu konferencja ta okazała się bowiem przełomem w stosunkach amerykańsko-radzieckich, rozpoczynając okres współpracy m.in. w kwestiach likwidacji światowego potencjału zbrojnego.

Najważniejszym wydarzeniem kolejnego „szczytu”, który odbył się w Moskwie wiosną 1988 r., miało być podpisanie przełomowego układu umożliwiającego poważną, bo 50-procentową redukcję strategicznej broni

singer stwierdził, iż „,z punktu widzenia Zachodu, mogą się w Rosji wydarzyć dwie rzeczy dla Zachodu katastrofalne. Po pierwsze, Gorbaczowowi plan reform się powiedzie, po drugie, że się nie powiedzie". Za: W. Malendowski, op. cit., s. 191.

32 J. Kukułka, Historia współczesna ..., op. cit., s. 419.

33 I. Korcziłow, Kulisy dyplomacji, Warszawa 1998, s. 42. 
nuklearnej oraz rakiet dalekiego zasięgu, ale chociaż Reagan i Gorbaczow prawie sześć miesięcy wcześniej wydali stosowne instrukcje powołanym grupom w Genewie, to nie udało się do tego czasu zakończyć rokowań START $^{34}$. Ograniczono się więc tylko do podpisania układu o ratyfikacji INF, wydano wspólne oświadczenie, w którym obie strony zobowiązały się do zapobiegania wszelkiej wojnie między nimi i zrezygnowania z dążeń do przewagi militarnej oraz uznały również potrzebę współdziałania

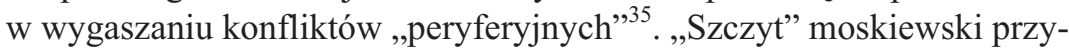
czynił się do nadania spotkaniom amerykańsko-radzieckim bardziej regularnego charakteru w oparciu o budowę wzajemnego zaufania.

Oceniając politykę zagraniczną Ronalda Reagana należy podkreślić jego rolę w zakończeniu zimnowojennej konfrontacji między mocarstwami i przejście do dialogu o skutkach ogromnych, zwłaszcza, że był on uważany w tamtym okresie za najbardziej konserwatywnego i antykomunistycznego z powojennych prezydentów Ameryki. Reagan zdobył sobie przydomek „Wielkiego Wizjonera”, na nowo definiując politykę Stanów Zjednoczonych w stosunku do Związku Radzieckiego.

Jednak już w tym czasie zarysował się głęboki kryzys gospodarczy i polityczny systemu sowieckiego, który doprowadził do dezintegracji Związku Radzieckiego - „, chociaż większość jego oznak pozostawała prawie do samego końca przesłaniana wskutek ustrojowej obsesji na punkcie tajności i tendencji izolacjonistycznych" - jak twierdzi Zbigniew Brzeziński ${ }^{36}$.

Wiele jest opinii dotyczących bezpośrednich przyczyn rozpadu ZSRR. Dla wielu znawców przedmiotu istotny wpływ na dezintegrację Związku Radzieckiego miały przemiany wewnętrzne zachodzące w samym imperium, związane z modelem polityki uprawianej przez Michaiła Gorbaczo$\mathrm{wa}^{37}$, poparte ujawniającymi się problemami narodów i narodowości

$34 \mathrm{~W}$ tamtym okresie traktat był gotowy w prawie $90 \%$, ale pozostałe $10 \%$ sprawiało państwom najwięcej kłopotów, mimo że Reaganowi zależało, aby ukoronować swą prezydenturę podpisaniem układu START, to jednak kierownictwo radzieckie nie było jednomyślne w tej kwestii. Za: R. Koslowski, F. V. Kratochwil, op. cit.

35 Podczas ,szczytu” moskiewskiego podpisano również kilka porozumień o wzajemnej współpracy, m.in. o przeprowadzeniu wspólnego eksperymentu w dziedzinie kontroli, a także o notyfikowaniu startu międzykontynentalnych rakiet balistycznych (na czym zależało zwłaszcza Stanom Zjednoczonym) i rakiet balistycznych wystrzeliwanych z okrętów podwodnych (na czym zależało ZSRR).

36 Z. Brzeziński, Wielka szachownica ..., op. cit., s. 109.

37 R. Koslowski, F. V. Kratochwil, Understanding Change in International Politics: The Soviet Empire's Demise and the International System, „International Relations 
imperium. Tendencje te doprowadziły w konsekwencji do powstania postulatów i deklaracji suwerenności poszczególnych republik; proces ten zapoczątkowały kraje nadbałtyckie ZSRR.

W działaniach bezpośrednich inicjatywę polityczną przejął Borys Jelcyn - najbardziej zagorzały przeciwnik Gorbaczowa, który wraz z przywódcami pozostałych republik słowiańskich - prezydentem Ukrainy Leonidem Krawczukiem i przewodniczącym Rady Najwyższej Białorusi Stanisławem Szuszkiewiczem - podpisał w Puszczy Białowieskiej pod Brześciem umowę o zakończeniu istnienia ZSRR (8 XII 1991) oraz proklamację Wspólnoty Niepodległych Państw.

Krytycy porozumień białowieskich nie mają żadnych problemów z odpowiedzią na pytanie, kto ponosi odpowiedzialność za rozpad imperium. Dla komunistów najwięksi ,zbrodniarze” to Michaił Gorbaczow, bo rozmontował KPZR, a przede wszystkim Borys Jelcyn, który bez likwidacji Związku Radzieckiego nie mógłby pozbyć się z Kremla Gorbaczowa. $Z$ kolei ludzie z dawnej ekipy Jelcyna, dyskretnie, ale jednoznacznie sugerują, że historia potoczyłaby się inaczej, gdyby nie Ukraina ${ }^{38}$.

Stawało się coraz bardziej jasne, że nadszedł także kres partii komunistycznej, jako wszechwładnej siły i kres Związku Radzieckiego w ogóle. Zaczęło się od Komunistycznej Partii Związku Radzieckiego; najpierw Gorbaczow zrezygnował z funkcji sekretarza generalnego, a później działalność KPZR została zawieszona ${ }^{39}$. To, co stało się potem - po sierpniowym puczu $1991 \mathrm{r}$. i po rozwiązaniu ZSRR w grudniu tego samego roku nazwane zostało rewolucją demokratyczną. Runął system państwa radzieckiego, kierowanego przez partię komunistyczną, rozpadał się ZSRR - republiki związkowe ogłaszały swą suwerenność.

25 grudnia 1991 r. na Kremlu opuszczono radziecką flagę, a podniesiono trójkolorową - rosyjską.

Rozpad supermocarstwa doprowadził do sytuacji, w której nie tylko „zniknął niezwykle ważny uczestnik stosunków międzynarodowych, którego działania miały często charakter globalny" w decydowaniu o pokoju świato-

Theory and the End of the Cold War" Richard Ned Lebow. Thomas Risse-Kappen, informacje ze zbiorów Columbia International Affairs Online CIAO, zamieszczone na stronach www.ciaonet.org (stan na 1 marca 2002).

381 grudnia 1991 roku Ukraińcy w zdecydowanej większości opowiedzieli się w referendum za niepodległościąi, jak twierdzą zwolennicy Jelcyna, to był prawdziwy koniec ZSRR.

39 P. Kościński, Pucz, który zniszczył ZSRR, informacje z bazy „Rzeczpospolita” www.rzeczpospolita.pl (stan na 29 marca 2002). 
wym, procesach bezpieczeństwa czy wpływie na stymulację konfliktów zbrojnych w wielu częściach świata. Jakkolwiek Rosja nie straciła całkowicie znaczenia w światowym układzie i nadal pozostaje ona największym terytorialnie krajem, a jej aspiracje do odgrywania znaczącej roli w kształtowaniu światowego porządku wciąż są bardzo duże. Postrzeganie Rosji jako kontynuatora Związku Radzieckiego zostało powszechnie zaakceptowane przez społeczność międzynarodowa, potwierdzając teze, że „ZSRR w sensie prawnym nie upadł. On przekształcił się w Rosję"

USA wygrały zimną wojnę, zniknął świat dwubiegunowy, zawalił się dotychczasowy porządek, a przede wszystkim rozpadł się Związek Radziecki. W dodatku wszystko dokonało się szybko i - jeśli nie liczyć konfliktów regionalnych, takich jak w Abchazji, Naddniestrzu, Osetii Południowej czy w Czeczenii - prawie pokojowo. Pojawienie się Rosji na arenie międzynarodowej, nowego podmiotu politycznego zdolnego wpływać na losy świata, jest jednym z pierwszych, widocznych skutków rozpadu ZSRR. I pomimo zmian ustrojowych, terytorialnych czy ludnościowych, państwo to stało się prawnym sukcesorem i kontynuatorem ZSRR powszechnie zaakceptowanym, wraz z jego przewodnią rolą, choć znacznie osłabioną, w kształtowaniu ładu międzynarodowego. Państwa członkowskie WNP już w 1992 r. podjęły uchwałę o kontynuowaniu przez Rosję członkostwa ZSRR w ONZ wraz ze stałym członkostwem w Radzie Bezpieczeństwa.

Wobec rozpadu ZSRR Stany Zjednoczone uznały Rosję za jego prawnego sukcesora, popierając jednocześnie jej starania o miejsce w Radzie Bezpieczeństwa. Zdecydowana postawa administracji prezydenta Busha wobec przemian wyrażała się w stosunku do byłych republik radzieckich, domagając się od nich przekazania broni jądrowej Rosji, aby w ten sposób stała się ona jedynym mocarstwem nuklearnym na obszarze byłego ZSRR.

Pewnej modyfikacji w podejściu do byłego rywala dokonała administracja Billa Clintona, choć w większej mierze kontynuując pomoc zapoczątkowaną przez George’a Busha, Clinton uległ złudnemu przeświadczeniu, że w wyniku zakończenia zimnowojennej rywalizacji oba państwa zdecydują się na większe zaangażowanie w wewnętrzne sprawy każdego z nich, natomiast w kwestiach międzynarodowych stosunki byłych rywali oparte będą na współpracy i wspólnym kształtowaniu postzimnowojennego ładu.

40 Z. Cesarz, Rozpad ZSRR i polityka zagraniczna Rosji jako zagadnienie współczesnych stosunków międzynarodowych, w: Problemy polityczne współczesnego świata, Z. Cesarz i E. Stadtmüller (red.), Wrocław 1996, s. 130. 
Głównymi architektami relacji USA-Rosja stała się tak zwana Trójka, w skład której wchodzili: wiceprezydent Al Gore, sekretarz skarbu Lawrence Summers (odpowiedzialny za pomoc finansową z Międzynarodowego Funduszu Walutowego i z Banku Światowego) oraz Strobe Talbot zastępca sekretarza stanu. „Trójka” odpowiadała za kształt stosunków już od 1993 r. ${ }^{41}$ Na początku kadencji strategia „Trójki” wobec Rosji polegała na całkowitej akceptacji i poparciu dla działań Jelcyna oraz na udzielaniu pomocy finansowej, co z oczywistych względów nie miało większego wpływu na poprawę sytuacji gospodarczej, a prowadziło jedynie do nasilenia korupcji, pogłębienia frustracji wśród społeczeństwa oraz narastania niechęci, a nawet wrogości, do Zachodu ${ }^{42}$. Oficjalną strategią stała się przedstawiona przez doradcę ds. bezpieczeństwa, A. Lake'a, jesienią 1993 r., strategia ,enlargement”, która zakładała rozszerzenie grona państw demokratycznych i wspieranie demokracji na świecie oraz udzielenie pomocy krajom budującym gospodarkę rynkową.

Od roku 1994 widoczna jest zmiana w polityce wobec Rosji i zastapienie koncepcji „strategicznego partnerstwa” przez koncepcję ,pragmatycznego partnerstwa”, wynikająca z „,narastania w Rosji poczucia oblężenia czyniącego ją bardziej niepewną i podatną na nacjonalizm, który w minionych latach skłonił ją do izolacji" ${ }^{\prime \prime}$. Modyfikacja stanowiska amerykańskiego następowała pod wpływem zmiany polityki zagranicznej Rosji, a przede wszystkim odchodzenia od prozachodniego nastawienia i akcentowania mocarstwowych ambicji.

Pierwszą kadencję prezydenta Clintona cechuje szeroko zakrojona pomoc gospodarcza, finansowa oraz współpraca w dziedzinie bezpieczeństwa, np. w dziedzinie nieproliferacji broni masowej - oba państwa były zainteresowane zapobieganiem ewentualnemu pojawieniu się nowych państw nuklearnych.

Druga kadencja Clintona odznaczała się spadkiem znaczenia Rosji w polityce zagranicznej USA, co nie oznaczało jednak całkowitej marginalizacji - co Moskwa zarzucała Waszyngtonowi. Podkreślano znaczenie strategiczne i rolę w kształtowaniu ładu międzynarodowego, lecz podejście do relacji z Rosją cechowało większe zdecydowanie i mniejsze ustępstwa -

41 Informacje ze zbiorów Kongresu Stanów Zjednoczonych: www.policy.house.gov/russia/ch4.html (stan na czerwiec 2001).

42 Ibidem.

43 J. Stachura, Stany Zjednoczone w stosunkach z Rosja, „Sprawy Międzynarodowe” 1996, nr 1, s. 13. 
widoczne zwłaszcza w postawie sekretarza stanu Madeleine Albright wobec ciagłego sprzeciwu Rosji w kwestii poszerzenia NATO o kraje Europy Środkowo-Wschodniej. Strategia, opierająca się na przeświadczeniu, że Stany Zjednoczone Ameryki Północnej są jedynym państwem zdolnym do działania w charakterze światowego lidera, od którego oczekuje się przywództwa, spowodowała dalsze ochłodzenie w stosunkach z Rosją, wynikające również z faktu rozszerzania NATO na kraje Europy Środkowo-Wschodniej, zaniechania przez Waszyngton współpracy w dziedzinie technologii nuklearnej oraz pogrążania się Rosji w chaosie gospodarczym i finansowym. Wszystkie te czynniki wpłynęły na zmniejszenie znaczenia Rosji jako głównego partnera USA w polityce globalnej.

Od 1995 r. zaczęto mówić o narastającym kryzysie w stosunkach między Kremlem i Waszyngtonem, będącym efektem fiaska zbyt uległej polityki Strobe'a Talbota, a z drugiej strony zbyt agresywnej polityki zagranicznej Borysa Jelcyna. W rezultacie w polityce Rosji wobec USA, a częściowo również w polityce Stanów Zjednoczonych względem Moskwy zaczęły odzwierciedlać się stare interesy, a nawet dawne cele. Moskwa zaczęła oddalać się od Zachodu, uprawiając swoją własną politykę globalną. Niezadowolone z przebiegu reform społeczeństwo rosyjskie, podżegane „rewelacjami” publikowanymi na łamach codziennych gazet, że „Zachód chce uczynić z Rosji państwo drugiej kategorii”,44, poparło całkowicie politykę „twardej ręki” uprawianą przez ekipę prezydenta Jelcyna. A świat z pozycji Kremla wyglądał jednoznacznie: wszyscy muszą liczyć się z polityką Moskwy, ponieważ może być ona niebezpieczna; na razie jest tylko nieobliczalna.

Zasadniczym celem, jaki przyświecał Rosji w 1996 r. w jej aktywności międzynarodowej, było utrwalenie statusu państwa jako wielkiego mocarstwa, mającego prowadzić w konsekwencji do odzyskania pozycji supermocarstwa. Służyć temu miał rozwój stosunków bilateralnych z mocarstwami, zwłaszcza z USA oraz z Chinami, aktywna działalność w ramach struktur regionalnych i globalnych oraz próby zwiększania wpływów rosyjskich w strategicznych dla niej regionach. Idea globalnego partnerstwa strategicznego między Rosją a USA, wysunięta przez rosyjską dyplomację już w 1994 r., nie wyszła nigdy poza sferę deklaracji i Rosja zrezygnowała z prób stworzenia swego rodzaju globalnego rosyjsko-amerykańskiego

44 S. Janecki, P. Cywiński, Świat wedlug Kremla, „Wprost” z 25 maja 1995, nr 22, s. $70-71$. 
kondominium. W roku 1995 mówiono już tylko o ,pragmatycznym partnerstwie”, rok później Jelcyn zapewniał Clintona o wielkim znaczeniu USA dla Rosji, nie wspominając o jakimkolwiek partnerstwie. Jedynymi dziedzinami, w jakich współpraca rosyjsko-amerykańska odbywała się bez większych zakłóceń, były kwestie technologii, ochrony środowiska i badań kosmosu. Nadal dzieliły ich kwestie tak strategiczne, jak poszerzanie procesu rozbrojeniowego (Rosja, pomimo zapewnień o ratyfikacji układu START II w 1996 r., dokonała tego dopiero w kwietniu 2000 r.) czy kwestia przystapienia państw Europy Środkowo-Wschodniej do NATO oraz „zacieśnienie współpracy Rosji z Iranem,"45.

Jako element gry politycznej wobec Stanów Zjednoczonych należy traktować rosyjskie próby stworzenia „trójkąta strategicznego”, zaproponowanego w Delhi w 1998 r. przez ministra spraw zagranicznych Jewgenija Primakowa Chinom i Indiom, w celu stworzenia alternatywnej siły w kształtowaniu ładu międzynarodowego ${ }^{46}$. Rok ten jak nigdy wcześniej potwierdził ścisły związek rosyjskiej polityki zagranicznej z sytuacją wewnętrzną w Rosji, próby realizacji ambitnej polityki globalnej zderzyły się z bolesnymi realiami gospodarczymi. Tak więc głównymi założeniami dyplomacji rosyjskiej w stosunku do Stanów Zjednoczonych stały się prośby o wsparcie dla przezwyciężenia ekonomicznej zapaści. Wyraźne jednak ochłodzenie w stosunkach rosyjsko-amerykańskich, a zwłaszcza przewartościowanie w strategii USA w stosunku do Rosji, w wyniku którego Rosja straciła na znaczeniu, spowodowały, że dyplomacja rosyjska nie odnosiła już tak spektakularnych zwycięstw. Poważnym ciosem, zwłaszcza dla międzynarodowego prestiżu Federacji Rosyjskiej, stały się naloty NATO na Jugosławię na początku 1999 r., którym Moskwa nie zdołała zapobiec i których nie mogła powstrzymać; ochłodzenie stało się faktem.

45 Współpraca Rosji z Iranem, nazwanym już w 1995 r. przez wicepremiera O. Dawydowa mianem ,strategicznego partnera”, niepokoiła zwłaszcza po zawarciu kontraktu rosyjsko-irańskiego na budowę do 2000 r. bloku energetycznego elektrowni jądrowej Bushehr w Iranie (wraz z dostawą reaktora), co mogło ułatwić realizację irańskiego programu zbrojeń jądrowych. Silne naciski na Rosję w celu rezygnacji z tego założenia nie przyniosły żadnych rezultatów. Dodatkowo zaniepokojenie w Stanach Zjednoczonych wywołała aktywizacja współpracy Rosji z Irakiem i Kubą, a zwłaszcza rosyjsko-iracki kontrakt w sprawie odbudowy przemysłu naftowego Iraku i współpracy w wydobyciu ropy naftowej.

46 A. Kuchins, Russia's Strategie Partnerships and Global Security, informacje z bazy, „The Carnerige Endowment for Intemational Peace” zamieszczone na stronach www.ceip.org (stan na listopad 2001 r.). 
Ostatnie lata prezydentury Jelcyna polegały na kontynuacji polityki „wodzenia Ameryki za nos”, obfitowały w nieobliczalne i irracjonalne zachowania prezydenta Rosji, nastawione na prowokacje i ośmieszenie Stanów Zjednoczonych. Akcentowanie mocarstwowych ambicji kłóciło się z polityką negocjowania i proszenia o pomoc finansową dla znajdującego w głębokim kryzysie gospodarczym molocha.

Oceniając stosunki amerykańsko-rosyjskie z okresu prezydentury Clintona i Jelcyna, można pokusić się o postawienie wniosku o braku właściwego podejścia do Rosji, charakteryzującego administrację amerykańską oraz o maksymalnym wykorzystywaniu tego faktu przez „nieobliczalnego" Jelcyna. Obok gigantycznej pomocy udzielonej Rosji z międzynarodowych oraz amerykańskich funduszy, które spowodowały w konsekwencji niesamowitą korupcję, razi również tolerancja wobec łamania w Rosji praw człowieka, a zwłaszcza klęski humanitarnej i ludobójstwa w Czeczenii. Nie można jednak polityce amerykańskiej odmówić pewnych sukcesów w kształtowaniu relacji między państwami, m.in. w powstrzymywaniu i odwodzeniu Rosji od bardziej agresywnych kroków w stosunku do jej bezpośredniego otoczenia, utrzymywaniu intensywnego dialogu z Moskwą czy włączaniu Rosji w różne formy międzynarodowej współpracy (NATO, przyłączenie Rosji do G-7). Stosunki w tym okresie charakteryzuje przechodzenie od daleko rozwiniętego partnerstwa między państwami, poprzez pragmatyzm i ochłodzenie relacji aż do „zimnego pokoju”. Rosyjskie ,wodzenie za nos Ameryki” oraz „,nieobliczalna", często agresywna polityka Jelcyna powodowała, że USA, poprzez stosowanie zasady „kija i marchewki”, nie uzyskiwały zamierzonego efektu. Kompromisowe podejście, odznaczające się pewną naiwnością oraz powierzchowną analizą amerykańskiej administracji spowodowało, że rosyjska dyplomacja odniosła w tym okresie o wiele więcej sukcesów, niż spodziewanoby się po państwie, które właśnie przegrało zimnowojenną rywalizację.

Na Zachodzie z ulgą przyjęto dymisję nieprzewidywalnego i kapryśnego prezydenta Jelcyna. Gdy tylko ustapił, od razu zarysował się przełom w postrzeganiu Rosji przez Zachód, liczono bowiem na bardziej przewidywalną politykę zagraniczną. Departament Stanu określił Władimira Putina jako człowieka z „listami uwierzytelniającymi reformatora"47.

47 „Ze świata”, informacje z bazy „Wprost” zamieszczonego na stronach www.wprost.pl (stan na 29 marzec 2002). 
Początkowa euforia ustąpiła jednak pod wpływem zachowań prezydenta Putina, który, porzucając idee partnerstwa, zapowiedział ograniczenie światowych wpływów Stanów Zjednoczonych jako strategiczny cel polityki zagranicznej Kremla. Poziom retoryki zawarty w szeregu dokumentów, m.in. w Doktrynie polityki zagranicznej FR, Doktrynie bezpieczeństwa informacyjnego FR oraz w nowej Doktrynie wojennej FR, przypominał ten z okresu ,zimnej wojny” i wskazywał na antyzachodni i przede wszystkim na antyamerykański kierunek polityki zagranicznej. Jak wskazuje A. Piontkowski, taka postawa Kremla świadczy o raczej impulsywnym i emocjonalnym charakterze zachowań w stosunku do USA w wyniku psychologicznego urazu po przegranej ,zimnej wojnie” przeżywanego przez rosyjską klasę polityczną ${ }^{48}$. Konsekwencją przyjęcia nowych doktryn było odejście od budowania polityki na zasadzie specjalnych stosunków z USA. Rosja zaczęła usztywniać swoją politykę - zarówno wobec Stanów Zjednoczonych, jak i krajów Europy Środkowo-Wschodniej. Cele stawiane nowej polityce przez Putina to: przełamanie dominującej pozycji USA na arenie międzynarodowej, szeroko pojęta „wielobiegunowość”, walka z rozszerzeniem NATO, stworzenie „strategicznego partnerstwa" z Chinami jako przeciwwaga bloku zachodniego, a także intensyfikacja działań dyplomacji rosyjskiej wobec Francji i Niemiec, w celu osłabienia sojuszu transatlantyckiego. Putin przypominał, że „Rosja nie dyskutuje o statusie mocarstwa, Rosja nim jest" ${ }^{\text {"R }}$, wysuwając jednocześnie roszczenia, że terytorium dawnego ZSRR powinno być uznane przez NATO jako wyłączna strefa rosyjskich wpływów i kontroli.

Wyraźne przewartościowanie w kierunkach polityki zagranicznej Federacji Rosyjskiej nastąpiło pod wpływem wydarzeń w USA 11 września 2001 roku. Rosyjski prezydent był jednym z pierwszych światowych liderów, który w bezpośredniej rozmowie telefonicznej nie tylko złożył kondolencje George'owi W. Bushowi i zapowiedział, że Rosja poprze wszelkie działania odwetowe przygotowywane przez Stany Zjednoczo$\mathrm{ne}^{50}$. Zaproponował udział wojsk rosyjskich w ewentualnych działaniach

48 A. A. Piontkowski, Nowy kurs rosyjskiej polityki zagranicznej i problemy bezpieczeństwa wojskowego, „Rocznik Strategiczny” 2000/01, red. E. Haliżak, R. Kuźniar, D. Popławski, H. Szlajfer, Warszawa 2002, s. 33.

49 Z. Raczyński, 12 prac Putina, informacje z bazy „Polityki” zamieszczonej na stronach www.polityka.onet.pl (stan na marzec 2001).

50 D. Doder, Tragedy can tighten U. S., Russian ties, „USA Today”, 20 września 2001, s. $13 \mathrm{~A}$. 
militarnych oraz przekazanie tajnych informacji dotyczących Afganistanu. Zgodził się również na udostępnienie rosyjskich baz wojskowych w Tadżykistanie i Uzbekistanie oraz wsparcie walczącego z Talibami Sojuszu Północnego, dostawami sprzętu wojennego ${ }^{51}$. Co więcej, ogłosił, że Rosja opuści bazę wojskową w wietnamskim Kamraniu i centrum wywiadu elektronicznego w Ludres na Kubie. I wreszcie, szybko wycofa wojska rosyjskie z Abchazji i Naddniestrza. Tak więc Rosja stanęła przed historycznym wyzwaniem pojednania się z Zachodem i przeorientowania swojej polityki zagranicznej z antyzachodniej na prozachodnią. Putinowska Rosja uznała się za sojusznika koalicji antyterrorystycznej.

Tak więc, ataki terrorystyczne w dniu 11 września 2001 r. w USA wpłynęły na zmianę w relacjach między oboma państwami. Wydarzenie to, tak tragiczne dla narodu amerykańskiego, zbliżyło oba mocarstwa ${ }^{52}$. Prezydent Rosji zdecydowanie poparł amerykańskie działania antyterrorystyczne, podkreślając, że Moskwa nie potrzebuje dalszych dowodów, by jej służby specjalne dołączyły do tej walki ${ }^{53}$. Tak zdecydowane poparcie Władimira Putina w tak trudnym momencie dla Ameryki wymagało wiele odwagi, zwłaszcza w obliczu faktu rosnących nastrojów antyamerykańskich wśród generalicji rosyjskiej. Na spotkaniu koalicji antyterrorystycznej w Brukseli w październiku 2001 r. Putin określił warunki, na jakich Rosja przystąpi do światowej koalicji, m.in. uznanie konfliktu w Czeczenii za wewnętrzny problem Rosji, utrzymanie wpływów Rosji w byłych republikach radzieckich, z wyjątkiem państw bałtyckich. Był to wynik pragmatyzmu Putina i nowej strategii wobec USA, aby krok po kroku doprowadzić do swego celu: powrotu Rosji do grona światowych decydentów.

Na pytanie zadane Alainowi Besançonowi ${ }^{54}$, kto najwięcej zyskał po wrześniowym ataku na Stany Zjednoczone, bez wahania odpowiedział: Rosja - „Rosjanie znowu mogą kontrolować Afganistan, i to na amerykański koszt. Stany Zjednoczone płacą swoimi pieniędzmi za stary sowiecki

51 T. J. Colton, M. McFaul, America's Reat Russian Alties, informacje z bazy „The Carnerige Endowment for International Peace" zamieszczone w Internecie, na stronach www.ceip.org (stan na grudzień 2001 r.).

52 D. Doder, op. cit., s. $13 \mathrm{~A}$.

53 L. McQuillan, J. Weisman, Bush seeks cooperation of Afghan people, „USA Today”, 26 września 2001, s. 5A.

54 Alain Besançon jest jednym z najbardziej znanych francuskich historyków i politologów, autorem prac o systemie komunistycznym, historii Rosji oraz intelektualnych źródłach leninizmu. 
sprzęt przejmowany przez tzw. Sojusz Północny. Rosja, w imię walki z terroryzmem, może bezkarnie masakrować Czeczenów. Wywierać naciski na »bliską zagranicę«: już nie tylko na Białoruś, lecz i na Ukrainę, Armenię czy Azerbejdżan. Zyski Moskwy po 11 września są tak znaczne, że uprawnione wydaje mi się pytanie, czy to nie po jej stronie należałoby szukać przyczyn tej rzekomej cezury w dziejach świata"55.

Wszyscy są jednak zgodni - jeśli Rosja chce odgrywać ważną rolę w stosunkach międzynarodowych, jeśli chce mieć realny wpływ na kształtowanie ładu międzynarodowego, musi porzucić konfrontację z Ameryką na rzecz współpracy. Henry Kissinger, stwierdzając, że „strategia Putina polega na stworzeniu partnerstwa ze Stanami Zjednoczonymi, co oznacza, że chciałby on realizować cele Rosji przy wsparciu amerykańskiej potęgi”, ${ }^{\circ 6}$, podkreślił przede wszystkim, że „rosyjska polityka wynika nie z osobistych preferencji, lecz z chłodnej oceny interesów Rosji" ${ }^{\text {"57}}$.

Na spotkaniu w Szanghaju w 2002 r. prezydenci George W. Bush i Władimir Putin doszli do porozumienia w sprawie budowy przez Stany Zjednoczone tarczy antyrakietowej. Prezydent Rosji zaproponował w zamian, aby oba kraje przeprowadziły największą w historii redukcję sił nuklearnych (po półtora tysiąca pocisków). Na początku XXI wieku mamy więc do czynienia - według Zbigniewa Brzezińskiego - z amerykańską hegemonią w sprawach międzynarodowych, zapoczątkowaną rozpadem Związku Radzieckiego i kresem dwubiegunowości świata ${ }^{58}$. USA, jako jedyne supermocarstwo, muszą zadbać o geopolityczny wymiar swojej polityki zagranicznej i skoncentrować się - zdaniem prof. Brzezińskiego na kluczowych rejonach świata, pełniąc rolę arbitra politycznego, zapewniając stabilizację i równowagę ${ }^{59}$. Tym kluczowym rejonem jest i będzie Eurazja, jako „szachownica, na której toczy się walka o światową hegemonię"60, zgodnie z panującą od lat zasadą: „kto panuje nad Eurazją, panuje nad światem".

55 Wywiad dla „Rzeczpospolitej” zamieszczony w Internecie na stronach www.rzeczpospolita.pl (stan na 29 marca 2002).

56 H. Kissinger, Doktryna Kissingera, informacje z bazy „Wprost” zamieszczonego w Internecie na stronach www.wprost.pl (stan na 29 marca 2002).

57 Ibidem.

58 Z. Brzeziński, Supermocarstwo $w$ poszukiwaniu partnera, informacje z bazy „Rzeczpospolita” zamieszczone w Internecie, na stronach www.rzeczpospolita.pl (stan na 29 marca 2002).

59 Z. Brzeziński, Wielka szachownica ..., op. cit., s. 109.

60 Ibidem. 
Jak twierdzi Zbigniew Brzeziński, ,szczególny charakter rosyjskiej ekspansji imperialnej wynika ze współzależności pomiędzy militarystyczną organizacją społeczeństwa rosyjskiego a imperatywem terytorialnym, który jest określany przez instynkt przetrwania"61. Wydaje się, że relacje Stanów Zjednoczonych i Rosji dopóty będą absorbowały, dopóki USA nie wypracują jednej strategii w postępowaniu z Rosją i będą to czynić konsekwentnie, z uwzględnieniem natury Rosjan i rosyjskiej mentalności.

\section{Summary}

The political relationship between the United States of America and the USSR determined the international relations during the period of the „,cold war”. The election of Mikhail Gorbachev to general secretary of the Communist Party was a turning point in international relations. Boris Yeltsin signed the agreement to disband the Soviet Union, which according to legal regulations was then transformed into Russia. B. Clinton, who accepted all of the decisions of Russian president, and also supported financially a number of new initiatives from B. Yeltsin, continued the good relationship between Russia and the USA instigated by G. Bush. The election of W. Putin to the Russian presidency was followed by a new strategy from Russia towards western countries, particularly towards the USA. Instead of following the strategy of partnership Putin tried to limit the influence of the USA on Russian policy. The situation changed after the terrorist attack on $11^{\text {th }}$ Sept. when W. Putin, President of Russia, was one of the first world leaders to assure G. Bush in an official phone call that Russia intended to support all military action taken by the USA against the perpetrators. If Russia intends to have a great influence on the international political relations and take part in international policy it should change its position towards USA into one of partnership and co-operation.

61 Z. Brzeziński, Spadek ..., op. cit., s. 8. 